\title{
Chilean young learners' perspectives on their EFL lesson in primary schools
}

Perspectivas de la niñez chilena acerca de su clase de inglés como idioma extranjero en establecimientos de educación primaria

\author{
Volumen 18, Número 1 \\ Enero-Abril \\ pp. $1-20$
}

Este número se publica el $1^{\circ}$ de enero de 2018

DOI: https://doi.org/10.15517/aie.v18i1.31323

Maria-Jesus Inostroza A.

Revista indizada en REDALYC, SCIELO

Revista distribuida en las bases de datos:

LATINDEX, DOAJ, REDIB, IRESIE, CLASE, DIALNET, SHERPA/ROMEO, QUALIS-CAPES, MIAR

Revista registrada en los directorios:

ULRICH'S, REDIE, RINACE, OEI, MAESTROTECA, PREAL, CLACSO 


\title{
Chilean young learners' perspectives on their EFL lesson in primary schools
}

\author{
Perspectivas de la niñez chilena acerca de su clase de inglés como idioma extranjero \\ en establecimientos de educación primaria
}

\begin{abstract}
Maria-Jesus Inostroza A. $^{1}$
Abstract: Latest research in the field of applied linguists suggests that giving children a participatory and active role in the development of their foreign language skills could help teachers reveal overlooked aspects of language learning. Furthermore, challenging the role given to children in language learning research could provide useful insights about the learning processes. In this regard, little is known in the field of primary English language teaching in Latin America. In the case of Chile, the Curriculum Framework for primary English language teaching considers the relevance of children's experiences as part of their learning process; however, reference to their active involvement in this process is still scarce. This article aims at identifying the perspectives about the English lesson of a group of fourth graders from state-funded schools in Chile. Through an exploratory study of qualitative nature, the viewpoints of 16 children are collected through semi-structured group interviews. The data from the four group interviews are interpreted by content analysis resulting into two categories, and five subcategories related to likes, dislikes, perceived value of learning English, hands-on activities and feedback. The findings suggest that given the chance, children are able to consistently reflect on their learning process and experiences. These learners pointed out preferences for hands-on activities and the relevance of opportunities for obtaining feedback as contributing experiences for successful language learning. Similarly, these results illustrate that, by considering perspectives from outside applied linguistics, researchers could uncover factors present in the language learning process.
\end{abstract}

Keywords: primary education, english, second language instruction.

Resumen: La investigación más reciente en el área de la lingüística aplicada sugiere que darles a los niños y a las niñas un papel participativo y activo en el desarrollo de habilidades de un idioma extranjero les permitiría a las personas docentes descubrir aspectos ignorados del proceso de aprendizaje de un idioma extranjero. Aunado a ello, cuestionar el papel que se le da a la niñez puede servir para develar los procesos de aprendizaje. En Latinoamérica, poco se sabe de este tema en el área de la enseñanza de inglés en Educación Primaria. En el caso de Chile, las bases curriculares para la enseñanza de inglés, en educación primaria, consideran que las experiencias de los y las infantes son relevantes para el proceso de aprendizaje. Sin embargo, se hace nula referencia al rol activo que tienen en este proceso. Este artículo tiene como objetivo identificar las perspectivas de un grupo de estudiantes de cuarto año de Educación Primaria de establecimientos educacionales, con financiamiento estatal en Chile, respecto de la clase de inglés. Mediante un estudio exploratorio cualitativo se recogen los puntos de vista de 16 estudiantes, a través de entrevistas grupales semi estructuradas. Los datos de las cuatro entrevistas grupales son interpretados con la técnica de análisis de contenido, que permitió levantar dos categorías y cinco subcategorías relacionadas con las actividades favoritas y menos preferidas, sus percepciones sobre el valor del aprendizaje de inglés, las actividades dinámicas y retroalimentación. Los resultados sugieren que, cuando se le da la oportunidad a la niñez, son capaces de reflexionar coherentemente acerca de sus procesos y experiencias de aprendizaje. Este grupo de estudiantes destaca la preferencia por actividades dinámicas, además de la relevancia de las oportunidades de obtener una retroalimentación. Asimismo, estos resultados ilustran que al considerar perspectivas fuera de la lingüística aplicada, los investigadores pueden descubrir factores poco explorados en el proceso de aprendizaje de un idioma extranjero.

Palabras clave: educación primaria, inglés, enseñanza de una segunda lengua.

1 Profesora asistente, Facultad de Educación, Universidad de Concepción, Chile, integrante de la Red Investigadores Chilenos en ELT (RICELT). MA in Applied Linguistics y $P h D$ in English Language and Linguistics, University of Sheffield, Reino Unido.

Dirección electrónica: minostrozaa@udec.cl

Artículo recibido: 3 de abril, 2017

Enviado a corrección: 24 de agosto, 2017

Aprobado: 13 de noviembre, 2017 


\section{Introduction}

A critical view has recently emerged from applied linguists on the role young learners (5 to 11-year olds) play in facilitating their own language learning processes. Giving children a participatory, active role in the development of their foreign language skills has been shown to help teachers and researchers address overlooked aspects of language learning.

Research carried out in the field of Teaching English to Young Learners (TEYL) has investigated cognitive and social developmental characteristics of young learners that could aid in learning a foreign language (Shintani, 2011; Tellier, 2008). However, most of this work has followed an experimental design in which children were exposed to certain conditions to later be tested (Kolsawalla, 1999; Peñate Cabrera and Bazo Martínez, 2001).

From a developmental perspective, children follow a set of stages of incomplete competence until adulthood. Therefore, they are more likely to be considered passive objects in social interactions, leaving little room for taking into account their perspectives on their own learning and life experiences (Pinter, 2014; Woodhead and Faulkner, 2008).

Considering insights from other disciplines and multiple paradigms provides researchers in applied linguistics the opportunity to look at their object of inquiry from different perspectives. In the case of TEYL, it challenges the role given to children in language learning research; at the same time, it questions the idea of young learners as incomplete beings.

This article reports on a qualitative exploratory study which sought to uncover the views of four groups of Chilean young language learners on their EFL lessons, as a way of responding to the need to listen to children's voices.

\section{Theoretical framework}

In recent decades, a new standpoint has emerged - the 'New Sociology of Childhood.' It defines children as social actors, who are able to contribute to the portrayal of their everyday life and understandings (James, Jerks, and Prout, 1998). Using this approach, James et al. (1998) have defined the child as "a person, a status, a course of action, a set of needs, rights and differences." (p. 207). They also describe the child as a socially constructed part of "the local rather than global phenomenon" (James et al., 1998, p. 214). Supporters of this approach argue that children are capable of providing useful and reliable insights into their own lives, and that they can be resourceful and knowledgeable, especially concerning 
their own experiences (Christensen and James, 2008; Christensen and Prout, 2002; Mayall, 2008).

In the field of applied linguistics and language teaching, there are few studies to date that acknowledge children as active participants, and which have been carried out with children (Pinter, 2014), as opposed to on children. In a seminal article, Pinter (2014) has argued that young learners are capable of reflecting on their language learning process and that these insights should be taken into account in teaching and research. Pinter (2014) has asserted that incorporating children as agents in research is beneficial for all parties involved, as it challenges the adult-centred knowledge structure and may contribute with new and different ideas about the way children learn a foreign language, the points they struggle with and their reasons for undertaking the learning. In her article regarding hearing children's voices in policy matters, Roberts (2003, p. 34) has argued that mechanisms need to be devised in order to be able to learn from successful experiences, and effectively involve children and young people in the policy making process.

\subsection{Researching with Young Language Learners}

Following this approach to researching with children, it is necessary to create instruments that allow researchers to involve children. In this line, alternative ways to approach data collection including children in research as active participants have been developed. Group interviews and focus groups (Pinter and Zandian, 2014; Yáñez and Coyle, 2011) are frequently used in researching with children. One of the main elements of this approach is to challenge the power gap in adult-child interaction. For instance, Kuchah and Pinter (2012) described a group interview with children in Cameroon which showed that by breaking the traditional power relations between children and adults, young learners were able to challenge the adults' perspective on the features of "good teaching" (Kuchah and Pinter, 2012). Similarly, in a study carried out by Turek (2013), the break in the power relationship allowed a group of children in Turkey to contribute to the design of a research instrument, which made the tasks "child-friendly" (Turek, 2013, p. 38), validating the data collection instrument and making findings more reliable. The findings from these studies could not have been uncovered through traditional methods on children. 


\subsection{Chilean EFL Context}

Chilean educational authorities have identified the development of English language skills as a way to bridge the gap of inequality, within what is currently a strongly classsegregated educational system (Committee of the Right of the Child, 2015; Valenzuela, Bellei, and de los Ríos, 2013). Currently, there are two main administrative entities for Chilean primary education: a) Municipal schools: public schools administered by the respective municipalities, generally with no entry requirements for pupils; b) Subsidised schools: schools administered by private non-profit or for-profit organisations that receive a public subsidy per student of the same amount as municipal schools, but have the possibility to charge entry and monthly fees (adapted from Santiago, Benavides, Danielson, Goe, and Nusche, 2013, p. 15).

Since 2005, the Chilean EFL curriculum for primary education is compulsory from $5^{\text {th }}$ Grade (10+) on; however, in 2013, the Ministry of Education (MoE) launched a suggested National Curriculum for EFL starting from $1^{\text {st }}$ Grade (6+). The set of overarching objectives to be covered during these years are mainly oriented towards developing communication skills, and follows "the guidelines of the Communicative Approach, complemented with other approaches with focus on communication" (Ministerio de Educación, 2012b, p. 1). For these early starters, the suggested Curriculum Framework aims to take into account children by providing them with opportunities to talk about different themes which "establish connections with their own experience and interests" (Ministerio de Educación, 2012a, p. 230); however, there is little consideration of their active involvement as part of their language learning process.

Similarly, research in the field of primary English language teaching and children's perspectives is still scarce in Chile and Latin-America (López-Gopar, 2014; Sayer and Ban, 2014).

\section{Methodology}

\subsection{Type of study}

This exploratory case study of qualitative nature examines the perspective of four groups of Chilean young learners on their EFL lesson.

This study forms part of a larger project that aimed at identifying the challenges that Chilean early primary school teachers face, and investigated the contextual factors that can facilitate or hinder the English language teaching-learning process (Inostroza A., 2015). 


\subsection{Objective of the study}

Identify the perspectives on their EFL lesson of four groups of Chilean young learners from four state funded schools. Two research questions aimed to be answered in this article:

- What are the young learners' perceptions of their current EFL lessons?

- What are these young learners' perceptions of their ideal EFL lesson?

\subsection{Participants}

This project was carried out in three middle and low-income communes from Santiago, the Chilean capital city, and it took place between March and June 2013. The four participating schools were state funded (municipal and subsided) and shared features regarding their location and the level of vulnerability of their student populations. These educational institutions had $70 \%$ to $90 \%$ of students for whom the socioeconomic status of their homes may hinder their ability to face the educational process; therefore, these schools receive the Preferential School Subsidy (SEP in Spanish) which aims to "improve the quality of education of the poorest areas and with the lowest educational achievements" (Corvalán, 2012, p. 7).

A total of 16 learners from four different $4^{\text {th }}$ Grade classes (9+) were interviewed in groups about their perceptions of their EFL lessons at the beginning and at the end of the semester (Table 1). These students belonged to each of the four participant classes in the larger project. Therefore, Group 1 was part of Class 1 and their EFL teacher was Teacher 1, and so on.

Table 1

Summary of the participants' details, Chile, July 2013

\begin{tabular}{ccc}
\hline Group & $\begin{array}{c}\text { Number of } \\
\text { learners interviewed }\end{array}$ & Learners' participants pseudonyms \\
\hline 1 & 4 & Valeria, Rosa, Paula and Carolina \\
2 & 4 & Flavia, Macarena, Milena and Susana \\
3 & 5 & Ester, Sabrina, Francisca, Isabel and \\
4 & 3 & Rocio \\
\hline
\end{tabular}

Source. Adapted from Inostroza (2015).

Consent was negotiated with parents first and then with children. Firstly, the project was explained to pupils' parents or legal guardians in a parents' meeting, and through an information letter. They were asked to sign a consent form allowing the pupils to be interviewed. Secondly, the learners were asked for their consent verbally every time they were invited to take part in the interviews. They were constantly told of their right to stop 
taking part in the research at any point, as well as reassured that their identities would be confidential and anonymised.

These children had EFL lessons as part of their compulsory primary education. As shown in Table 2 below, most of them had 1.5 hours of EFL lessons a week, and an average of 3 years of EFL instruction. There were over 34 students in these classes. Regarding their English level, according to the CEFR levels, two teachers were $\mathrm{C} 1$ proficient users, and two B2 independent users. Interestingly, only one of these teachers was an EFL specialist, and the other two were primary teachers with EFL training. This seems to be the tendency in Chilean primary schools, in which primary teachers seek out subsequent EFL qualifications to teach in this level.

Table 2

Details of the participants' classes, Chile, July 2013

\begin{tabular}{lcccc}
\hline Detail & Class 1 & Class 2 & Class 3 & Class 4 \\
\hline STUDENT & & & & \\
Number of students & 34 & 37 & 40 & 43 \\
EFL hours a week & 1.5 & 1.5 & 3 & 1.5 \\
$\begin{array}{l}\text { Years of instruction } \\
\text { TEACHER }\end{array}$ & 4 & 2 & 4 & 2 \\
Qualifications & Primary & Primary & Secondary & Teacher of \\
EFL Training & teacher & teacher & EFL teacher & French \\
English Proficiency & $\checkmark$ & $\checkmark$ & $\checkmark$ & $\checkmark$ \\
SCHOOL & ALTE 4. C1 & ALTE 3, B2 & ALTE 4. C1 & ALTE 3, B2 \\
$\begin{array}{l}\text { Type } \\
\text { Gender }\end{array}$ & Municipal & Municipal & Subsidised & Subsidised \\
\multicolumn{1}{c}{ Source. Adapted from } & mixed & Girls only & Mixed \\
\hline
\end{tabular}

Source. Adapted from Inostroza (2015).

In the first two weeks, children were observed in their interactions inside and outside the classroom. During this time, some students were pre-selected as they were able to express their ideas and share their reflections. The researcher interaction with the learners during recreational breaks and lunch time allowed her to identify friendship relations, as well as to develop closeness with some of them. Following the literature on researching with children (Kuchah, 2013; Kuchah and Pinter, 2012; Lewis, 1992; Mayall, 2008), the learner participants were finally selected by their friendship relationships, as well as trust and closeness developed with the researcher during those weeks. The number of students in 
each interview was always four. One participant from the first interview changed in the second, due to changes in friendship relationship during the semester.

All of the students interviewed were girls; even when there was some interaction with boys from the different classes, there was not enough time and contact to be able to develop rapport to invite them to take part in the group interviews (reflections on this issue are presented later in this article).

\subsection{Data collection instrument and procedure}

In order to collect learners' perspective, two semi-structured interviews were used. This type of interview allowed children to guide the conversation into spontaneous comments away from the researcher's planned themes (Christensen and Prout, 2002). At the beginning of the academic semester (April), the interview focused on eliciting the children's opinions about their EFL lessons asking questions regarding the things they liked about their lessons, as well as their opinions about their teacher and materials (see appendix 1). In this interview, some general questions regarding children's classmates and classroom were included in order to make children to feel at ease. At the end of the term (June), the questions concentrated on any changes in the lesson or their teacher since the beginning of the semester, and a description of their ideal EFL lesson (see appendix 2).

The interviews were carried out in the participants' first language, Spanish. The data transcriptions and analysis were done in the language they were generated in order to maintain the information as faithful as possible from the original data. Extracts presented in this article were translated by the researcher for report purposes. The use of English in the original interviews is noted by the use of bold text.

\subsection{Data analysis}

The interview data was analysed following content analysis and using NVivo 10 to process the data. A set of sub-categories based on the interview themes were used to start the analysis; however, some of the final sub-categories and all of the codes emerged from the data as it can be seen in Table 3. 
Table 3

Summary of analytical categories, sub-categories and codes, Chile, July 2013

\begin{tabular}{|c|c|c|}
\hline Categories & Subcategories & Codes \\
\hline \multirow{6}{*}{ 1. EFL lesson } & \multirow{2}{*}{ 1.1. Likes } & Challenging activities* \\
\hline & & Fun* \\
\hline & & Difficult* \\
\hline & 1.2. Dislikes & Opportunities to \\
\hline & \multirow{2}{*}{$\begin{array}{l}\text { 1.3. Perceived value of } \\
\text { learning English* }\end{array}$} & $\begin{array}{l}\text { Future use of learning } \\
\text { English* }\end{array}$ \\
\hline & & Personal Satisfaction* \\
\hline \multirow{6}{*}{$\begin{array}{l}\text { 2. Ideal EFL } \\
\text { lesson }\end{array}$} & \multirow{5}{*}{ 2.1. Hands-on* } & Act $^{*}$ \\
\hline & & GW with friends* \\
\hline & & Handicraft* \\
\hline & & Oral activities* \\
\hline & & Games in general $^{*}$ \\
\hline & 2.2. Feedback* & Formative feedback* \\
\hline
\end{tabular}

Note: categories and codes with * derived from the data analysis.

Source. Adapted from Inostroza (2015)

Once all the codes were identified, they were reviewed by a second researcher in the field of TEFL in the Chilean context. This researcher was given an evaluation form to provide feedback and comments on the codes definitions. Finally, the inter-coder agreement coefficient, $97.03 \%$, showed the reliability of the analysis.

\section{Findings}

Findings will be presented in accordance to the categories and sub-categories presented on Table 3 above.

\subsection{Category 1: The EFL Lesson}

The four groups of YLLs interviewed identified a set of characteristics about their EFL lessons. The questions in this first interview were focused on the things they enjoyed and did not enjoy about the lessons.

\subsubsection{Sub-category 1.1: Likes}

In this interview, children concurred in their enjoyment of their EFL lessons, being the most repetitive characteristic that it was 'fun.' At this point they did not develop their ideas 
further or provide examples or reasons. Most of the comments were more of a cyclical argument in which the lesson is fun or entertaining because they like it and vice versa:

Valeria: Fun.

Rosa: Fun, yes.

Valeria: We really like English because it's fun.

Rosa: It's fun. (Group 1, April)

These children really appreciated challenging activities as these types of activities motivated them to be involved and attentive during the lesson:

$\mathrm{R}:$ (...) What do you like the most?

Macarena: I like when the teacher speaks, it's like we don't know, and like we have to know what he wants to say. (Group 2, April)

R: What do you like the most of the course book? (...)

Mireya: I like that we do not understand what it says.

$\mathrm{R}$ : Is that what you like or what you don't like?

Mireya: What I do like! (Group 4, April)

\subsubsection{Sub-category 1.2: Dislikes}

Among the things they dislike about their lesson, two groups expressed their views regarding two main points: difficulty and scarce opportunities to participate. Girls in Group 2 described their experience in the EFL lesson as 'difficult.' This difficulty referred to English as a subject:

Flavia: And sometimes, he says words in English, like we have to understand them, like we have to think about the (...)

Macarena: It's complicated. (...)

Flavia: The stuff that are in front of, next to, above, behind

Milena: Yes, that's difficult for me. (Group 2, April)

For this group of learners, English is a subject like any other. From their opinions, it was not possible to identify any references to English as a language, or the value of English to communicate with others. This contradicts what is expected from the MoE orientations. 
According to the National Syllabus, the overarching objectives are mainly oriented to developing communication skills (Ministerio de Educación, 2012a, p. 1).

Group 3 made it clear that they felt frustration for not being able to participate in the lesson as much as they liked, with 'limited opportunities to participate.' These girls referred to experiences in which the teacher considered only a small number of students for answering questions:

Ester: It shouldn't be like that. I mean, I get a bit sad when everyone puts up their hands, and I do it as well because I know that I can answer correctly, and the teacher chooses another girl, and she answers correctly, and I feel like <angry face> (...)

Sabrina: I get really angry when, this is just an example, Rocio puts up her hand she is always, always picked to answer, then I get like <angry face> (...)

Isabel: ...sometimes our group is not picked for answering questions <to the teacher>, because they say "why asking that group, if that group already knows" Sabrina: Yeah! I hate that! (Group 3, April)

\subsubsection{Sub-category 1.3: Perceived value of learning English}

These girls give value to learning English as it is related to personal reasons, such as their musical preferences, and their individual desire to communicate and help others. These intentions seem to go beyond the social discourses (Bakhtin, 1986, p. 93) of teachers and family around them regarding the relevance of speaking English in this globalised world.

From a more individual driven standpoint, learning English is perceived as something that provides girls in Groups 1 and 3 with 'personal satisfaction.' Being able to model behaviour, to support peers or to get others' attention gave these learners personal fulfilment. They mentioned that it allowed them to share their knowledge with others in their close environment:

Rosa: A classmate gave me a poster, the one that sits next to me, which was written in English, and he didn't know what it said, and told me "I don't understand, could you translate it for me?" and I told him then the stuff, and he looked at me like <question face> (Group 1, April) 
Francisca: I like English because when I visit my uncles and aunts, my uncles and aunts say "speak in English", and I speak in English and there everyone gets really impressed about the way I speak. (...).

Ester: [...] because sometimes I tell my dad, for example "look I'm wearing a hat" and he says "what does that mean?" and I say "A hat! I'm going to give you lessons", and the following day we give him a lesson, we take out our notebook and we say "write that down". [...].

Francisca: When I learn words, I go home and tell them to my mum, and then every time I am learning more, I think I could become a teacher and I teach some girls so they can learn English and learn to communicate. (Group 3, April)

Drawing from these opinions, they showed that they were proud of their language skills and of being able to support others in learning English. It can be inferred that these learning aims are their own and individual to these groups of girls, as they differ from the teacher's agenda (Kuchah and Pinter, 2012).

\subsection{Category 2: The Ideal EFL Lesson}

The four groups of YLLs were also asked about what their ideal EFL lessons would be like. This question was included in order to compare their impression of their current lesson and an ideal one. They mentioned elements that were present after the intervention, such as games, role play and oral activities, but they also suggested some other activities, namely revision tasks and handicraft activities.

\subsubsection{Sub-category 2.1: Hands-on}

In the second interviews children expressed their preferences for activities in which they had to act and/or move. In particular, they mentioned their interest into games, acting out and oral activities.

Group 3, for instance, clearly voiced their involvement in tasks which allowed them to learn through acting out or doing role plays, and which developed their creativity at the same time as playful personality:

Isabel: ... like today, it was like fun because we had to go to the front like that, and act out, and we haven't done that before, and also, also, like the stuff with the 
occupations, I think it is great fun because there were some occupations that we didn't see with Miss Ingrid. [...]

Sabrina: [...] And also because in the, like what Isabel had said, now we do more activities that we have to act like occupations, you have to pretend you are a fire fighter, and that is more fun for a girl [...] And that, I don't know, we like that the most because we don't have to write that much, and we could be more creative and to be whatever we want, like a vendor who is a clown and helps, and who is really funny, so you like those stuff and you laugh! (Group 3, May).

Similarly, Group 4 suggested Handicrafts as an example of effective and meaningful activities to experience the language by doing:

Fabiola: I'd like to do more interactive stuff. Stuff with plasticine or anything but in English

R: With plasticine?

Fabiola: With anything, for example, in English if we learn the body parts, and we make a figure and we label it, like that in English. (Group 4, June)

These groups of YLLs also identified learning, practising and revising as aims of games in the EFL lessons.

Isabel: I'd like if they would ask for my opinion to say how l'd like the EFL lesson to be, like I like writing, but with more activities, less writing; and the activities aren't for the girls to misbehave with the teacher, the activities are for us to learn and to summarise the content seen, and l'd like for the lesson to be with a lot of activities and less writing.

$\mathrm{R}$ : And when you say activities, what do you mean? What's for you an activity? Isabel: Like what we did today, the teacher called us to the front Ester: Like games. (Group 3, May)

Ester: l'd like for English lesson to have more games for revising, not much writing or copying from the board or fill in the blanks, but riddles or guessing word games, acting, and things like that. (Group 3, May) 
Paloma: With a lot of activities of doing, not writing

$\mathrm{R}$ : OK, for example

Paloma: For example, like the one we did the other day when we had to be part of a contest and say only words in English

$\mathrm{R}$ : OK, you liked that one.

Mireya: I liked it too. (Group 4, June)

These perspectives are consistent with the literature in TEYL that suggests that children enjoy activities which are meaningful and closer to their life experiences, such as pretending to be (Pinter 2006).

\subsubsection{Sub-category 2.2: Feedback}

For some of these girls, it was relevant to obtain formative feedback from their teachers during the lesson. They reported that questions from the teachers at the end of an activity could help them to remember, check their comprehension and revise content for future lessons:

Flavia: Learning to make the words, like Milena said, because it's hard for us, to learn them in Spanish. We know the words, but learning, reviewing, that's what is a bit harder for us -We are learning anyway. (...)

R: And do you like it? Is it OK the way you're doing it, or would you like to have more [songs and videos]?

Flavia: A bit more to learn more, so in other years they could help us to review, I mean see other contents and what we know about English, from last year. So we learn.

Macarena: Knowing what it is

Milena: Do it like you do it, Miss, recording and then, for example, for example in 5th Grade we watch it and we remember it and we start reviewing the same words. (Group 2, May)

Francisca: In my opinion, I like writing, but I really think that it's kind of fun to do activities because in that way people have fun, but l'd also like for the teacher, for example when we finish, every group finishes doing the activities like the one we 
did today, he would say, he asks questions, like apart from having it summarised, so it also helps us more with the questions that he asks.

$\mathrm{R}$ : And questions about what, for example?

Francisca: For example, like we did about a, let's say it's a firefighter and that we have to do a role play activity, where we perform. And after all the groups, he asks us questions about what we did. (Group 3, June)

This illustrates the relevance of including children's perspective on the assessment process as a way of monitoring their own learning experience. According to Brown (Brown, 2004 , p. 6), this type of assessment involves "evaluating students in the process of "forming" their competencies and skills with the goal of helping them to continue that growth process." In Hasselgren's (2000) article on an innovative approach for assessing English skills of young learners in Norway, the teacher's assessment was supposed to be complemented with the children's self-assessment, in order to assess the progress of young learners' skills. This illustrates that teachers and learners could benefit from providing children with the opportunity to contribute to their own learning, and to make them feel part of the teaching/learning process.

\subsubsection{Listening to learners' perspective}

This study provides findings which are consistent with the work of scholars that highlight the role of children as social actors with a personal language learning agenda (Pinter and Zandian, 2014).

The children reported that their EFL lessons were enjoyable, interesting and challenging. Some of them indicated that learning English was valuable. In their daily experiences, they mentioned that it allowed them to share their knowledge with family and friends; they also indicated that it could be important in the future to communicate with different people. For other learners, English was a difficult subject, and in some cases, they felt frustrated by not being able to participate as much as they would like in the lessons.

The four groups consistently reflected upon their learning process and what they liked about the EFL lessons. They explicitly referred to activities that they enjoyed as the ones in which they are active, moving and acting while using the language — doing rather than writing. In addition, they expressed their preference for tasks in which they can interact and 
work with others in collaboration. These perspectives are consistent with the literature in TEYL that suggests that children enjoy activities which are meaningful and closer to their life experiences (Brewster, Ellis, and Girard, 2002; Cameron, 2001; Moon, 2005; Pinter, 2006).

An interesting finding that emerged from this study was these children's detailed descriptions of "effective" tasks. Among the tasks, it was possible to identify stages of practice and assessment which were narrated in depth. Similarly, opportunities of interaction with the language and feedback were highly relevant for these children.

\section{Conclusion}

The article presented results from group interviews with learners from a sole group per class with only girls as participants. Even when these findings are relevant and provide valuable information, they should be taken with caution, as they are not necessarily representative of all the learners in those classes. It would have been beneficial to interview a wider range of children from each class. Unfortunately, the short timeframe of data collection at the schools restricted closeness and rapport with more children; diversity of learner participants would have provided a wider spectrum of perspectives. In addition, the sample only involved four schools from the capital city. Therefore, these findings may not necessarily reflect the realities of other school in the city or smaller cities in the country which are still considered to be urban.

Despite these limitations, the findings presented confirmed the assumption that children have an ability to effectively reflect on their language learning processes and personal motivations for learning English (Kuchah and Pinter, 2012; Pinter and Zandian, 2014, 2015).

Getting to know children's learning experiences, and taking them into account, provides useful insights about the learning processes and expectations of young learners. First, teachers could take advantage of this knowledge by reflecting on their teaching and the impact that it has on learning. Reflective practice (Rebolledo, Smith, and Bullock, 2016) could provide teachers with guidelines for improving teaching materials and strategies, getting feedback and allowing children to contribute with what seems to be more relevant for them. Secondly, policy makers and early start programme designers could benefit from children's insights, since it has been shown here that there are some discrepancies between what is expected from young learners and the way they understand learning EFL. Likewise, and given the cultural diversity in Latin America, valuable knowledge may be generated in relation to young learners' views on EFL versus learning an indigenous language. Furthermore, if 
more and more countries in Latin America are investing resources in implementing primary English language teaching programmes from an early age, they will need to consider these learners' perspectives on learning this language.

Finally, these findings show the benefits of noticing and incorporating insights from other areas of social sciences, such as sociology, geography, education, in order to challenge and reveal unexplored elements within applied linguistics and language education.

\section{Acknowledgements}

This work was supported by the National Commission for Scientific Technological Research of the Republic of Chile (CONICYT), through Becas-Chile Scholarship 2011 (Record No. 72120462).

\section{References}

Bakhtin, Mikhail Mikhailovich. (1986). Speech Genres and Other Late Essays. Austin, Texas: University of Texas Press.

Brewster, Jean, Ellis, Gail, \& Girard, Denis. (2002). The Primary English Teacher's Guide (New Edition). London: Pearson Education Limited.

Brown, H. Douglas. (2004). Language Assessment: Principles and Classroom Practices $\left(1^{\text {st }}\right.$ ed.). White Plains, New York: Longman.

Cameron, Lynne. (2001). Teaching languages to Young Learners. Cambridge: Cambridge University Press.

Christensen, Pia, \& James, Allison. (2008). Researching with Children: perspectives and Practices. ( $2^{\text {nd }}$ ed.). New York: Routledge.

Christensen, Pia., \& Prout, Alan. (2002). Working with Ethical Symmetry in Social Research with Children. $\quad$ Childhood, 9(4), 477-497. doi: https://doi.org/10.1177/0907568202009004007

Committee of the Right of the Child. (2015). The Convention on the rights of the child. United Nations. [digital version in pdf]. Retrieved from https://doi.org/10.2307/4065371

Corvalán, Javier. (2012). La Subvención Escolar Preferencial en Chile: Mirada a su primera fase de funcionamiento. Santiago: Programa de la Promoción de la Reforma Educativa en América Latina y el Caribe. Santiago, Chile: PREAL. Retrieved from http://www.thedialogue.org/wp-content/uploads/2013/03/preal-auditoria-2012ok.pdf

Hasselgren, Angela. (2000). The assessment of the English ability of young learners in Norwegian schools: an innovative approach. Language Testing, 17(2), 261-277. doi: https://doi.org/10.1177/026553220001700209 
Inostroza Araos, Maria-Jesus. (2015). Examining challenges and complexities in the Chilean young learner classroom: a case of teaching English as a foreign language (PhD Thesis, University of Sheffield). Retrieved from http://etheses.whiterose.ac.uk/11397/

James, Allison, Jerks, Chris \& Prout, Alan. (1998). Theorizing childhood. Cambridge: Polity Press.

Kolsawalla, Havovi. (1999). Teaching Vocabulary through Rhythmic Refrains in Stories. In Shelah Rixon (Ed.), Young Learners of English: Some Research Perspectives (pp. 1831). Essex: Pearson Educational Publishing.

Kuchah Kuchah, Harry. (2013). Context-Appropriate ELT Pedagogy: An Investigation in Cameroonian Primary Schools. (PhD Thesis, University of Warwick) Retrieved from http://wrap.warwick.ac.uk/58585/

Kuchah, Kuchah and Pinter, Annamaria. (2012). 'Was this an interview?' Breaking the power barrier in adult-child interviews in an African context. Issues in Educational Research, 22(3), 283-297. Retrieved from http://wrap.warwick.ac.uk/53137/

Lewis, Ann. (1992). Group Child Interviews as a Research Tool. British Educational Research Journal, 18(4), 413-421. doi: http://dx.doi.org/10.1080/0141192920180407

López-Gopar, Mario. E. (2014). Teaching English critically to Mexican children. ELT Journal, 68(3), 310-320. doi: https://doi.org/10.1093/elt/ccu017

Mayall, Berry. (2008). Conversations with Children: Working with Generational Issues. In Pia Christensen and Allison James (Eds.), Researching with Children: Perspectives and Practices (pp. 109-124). New York: Routledge.

Ministerio de Educación, Chile. (2012a). Bases Curriculares 2012: Idioma Extranjero Inglés Educación Básica. Santiago, Chile: MINEDUC. Retrieved from http://www.curriculumenlineamineduc.cl/605/articles-21319_programa.pdf

Ministerio de Educación, Chile. (2012b). Propuesta Curricular Educación Básica, Fundamentos y Objetivos: Idioma Extranjero Inglés. Santiago, Chile: MINEDUC. Retrieved from http://www.curriculumenlineamineduc.cl/605/articles18984_programa.pdf

Moon, Jayne. (2005). Children learning English. Oxford: Macmillan Education.

Peñate Cabrera, Marcos, \& Bazo Martínez, Plácido. (2001). The effects of repetition, comprehension checks, and gestures, on primary school children in an EFL situation. ELT Journal, 55(3), 281-288. doi: https://doi.org/10.1093/elt/55.3.281

Pinter, Annamaria. (2006). Teaching Young Language Learners (1 ${ }^{\text {st }}$ ed.). Oxford: Oxford University Press.

Pinter, Annamaria. (2014). Child Participant Roles in Applied Linguistics Research. Applied Linguistics, 35(2), 168-183. doi: https://doi.org/10.1093/applin/amt008 
Pinter, Annamaria., \& Zandian, Samaneh. (2014). 'I don't ever want to leave this room': benefits of researching "with" children. ELT Journal, 68(1), 64-74. doi: https://doi.org/10.1093/elt/cct057

Pinter, Annamaria., \& Zandian, Samaneh. (2015). 'I thought it would be tiny little one phrase that we said, in a huge big pile of papers': children's reflections on their involvement in participatory research. Qualitative Research, 15(2), 235-250. doi: https://doi.org/10.1177/1468794112465637

Rebolledo, Paula., Smith, Richard., \& Bullock, Deborah. (2016). Champion teachers: Stories of exploratory action research. [digital version pdf]. Retrieved from http://englishagenda.britishcouncil.org/books-resource-packs/champion-teachersstories-exploratory-action-research

Roberts, Helen. (2003). Children's participation in policy matters. In Christine Hallett \& Alan Prout (Eds.), Hearing the voice of children: social policy for a new century (pp. 26-37). London: RoutledgeFalmer.

Santiago, Paulo., Benavides, Francisco, Danielson, Charlotte, Goe, Laura \& Nusche, Deborah. (2013). OECD Reviews of Evaluation and Assessment in Education: Teacher Evaluation in Chile. Paris: OECD Publishing. doi: http://dx.doi.org/10.1787/22230955

Sayer, Peter., \& Ban, Ruth. (2014). Young EFL students' engagements with English outside the classroom. ELT Journal, 68(3), 321-329. doi: https://doi.org/10.1093/elt/ccu013

Shintani, Natsuko. (2011). A comparative study of the effects of input-based and productionbased instruction on vocabulary acquisition by young EFL learners. Language Teaching Research, 15(2), 137-158. doi: https://doi.org/10.1177/1362168810388692

Tellier, Marion. (2008). The effect of gestures on second language memorisation by young children. Gesture, 8(2), 219-235. doi: http://dx.doi.org/10.1075/gest.8.2.06tel

Turek, Agnieszka. (2013). Engaging Young Learners in L2 Research. Language Studies Working Papers, University of Reading, 5, 32-40. Retrieved from http://www.reading.ac.uk/web/FILES/english-language/elal_5_Turek.pdf

Valenzuela, Juan Pablo, Bellei, Cristian., \& de los Ríos, Danae. (2013). Socioeconomic school segregation in a market-oriented educational system. The case of Chile. Journal of Education Policy, 29(2), 217-241. doi: https://doi.org/10.1080/02680939.2013.806995

Woodhead, Martin, \& Faulkner, Dorothy. (2008). Subjects, Objects or Participants: Dilemmas of Psychological Research with Children. In Pia Christiansen \& Allison James (Eds.), Research with Children: Perspectives and Practices (pp. 10-39). London: Routledge.

Yáñez, Lorena, \& Coyle, Yvette. (2011). Children's perceptions of learning with an interactive whiteboard. ELT Journal, 65(4), 446-457. doi: https://doi.org/10.1093/elt/ccq069 


\section{Appendices}

\section{APPENDIX 1: STUDENTS' INTERVIEW: APRIL}

Thank you for talking to me. The reason of this conversation is that you could share with me your experiences in your English class. What you tell me will help me to tell teachers of English in other places about what children think about learning English at school. However, you are not forced to share anything that you do not feel comfortable with, so please feel free to talk only if you want to do so. At any time during our conversation, you can decide to stop talking to me, without having to give a reason. I will record our conversations so that I can remember what we said, but these recording will be stored in safe place with no access to your personal information. Thus, I will NOT share with your teacher, your parents or anybody in the school what you say here. There is no right or wrong answers; therefore, the success of our conversation depends on that your answers are according to what you really believe.

\section{THE CLASS}

1. How is your class? What do you like or do not like about it?

2. How is your classroom?

\section{ENGLISH LESSON}

3. What is the English lesson like? Could you describe a regular lesson?

4. What do you like/hate of them the most?

5. Could you tell me something that you have learnt in these lessons?

6. How is your teacher like? What do you like/hate about your teachers?

7. Have you got a textbook for your English lesson? Do you use it? Do you like it? Why? 


\section{APPENDIX 2: STUDENTS' INTERVIEW: JULY}

Thank you for taking to me. The reason for this conversation is that you share with me your experiences in your English class so far. What you tell me will help me to tell teachers of English in other places about what children think about learning English at school. You are not forced to share anything that you do not feel comfortable with, so please feel free to participate as far as you are comfortable. At any time during our conversation, you can decide to stop talking to me, without having to give a reason. I will record our conversations so that I can remember what we have said, but these recording will be stored in safe place with no access to your personal information. Thus, I will not share anything of what you say here with your teacher, your parents or anybody in the school. There is no right or wrong answers; therefore, the success of our conversation depends on that you are as truthful as possible regarding your experiences.

\section{ENGLISH LESSON}

1. What is the English lesson like?

a. Have you seen any changes between you lesson now and the beginning of the semester? In what way?

2. How would you like your lesson to be? What would you like to do in your English lesson? How would it be an ideal English lesson?

3. How is your teacher like now? Has she changed in any way as she was last year? 